\title{
John Chrysostom's Catechesis on Baptism in context of the late Fourth-Century Mystagogies
}

\author{
Prof. PhD. Pablo Argárate \\ Institute for Ecumenical Theology, Eastern Orthodoxy, and Patristics \\ Faculty of Catholic Theology, University of Graz, \\ AUSTRIA, \\ E-mail: pablo.argarate(at)uni-graz.at
}

\begin{abstract}
In the use of the united Church from the late forth century was developed the catechumenate, meaning a long and profound preparation for Christian Initiation, usually received in the Easter Vigil. However, candidates would receive explanation of the rites only after they were performed, namely during the Easter week. This practice was based on the so-called mystagogical method, the conviction that rites speak by themselves in a powerful manner. The Catechesis of Jerusalem (of Cyril or John, his successor), the Catechetical Homilies of Theodore of Mopsuestia along with the Baptismal Homilies of John Chrysostom in the East, but also both treatises (De mysteriis and De sacramentis) of Ambrose of Milan witness with different nuances to the mystagogical approach, namely the introduction into the mysteries and the Mystery itself by means of ritual actions. In the present study, I will focus on John Chrysostom's Baptismal Homilies, underlining some aspects: their timely framework, their connection with other similar texts and the general structure of the preparation for the Christian Initiation.
\end{abstract}

Keywords: Saint John Chrysostom; catechumenate; mystagogical method; catechesis;

\section{Introduction}

While in the Eastern Churches the Fathers have always constituted a central and essential element of their theology and spirituality, the same cannot be said of the Western Churches. Whereas the Roman Catholic tradition kept them to some extent, their role in Protestantism was very reduced, if existent at all. Roman Catholic rediscovery of the sources (not only Patristic but also biblical and liturgical) produced a powerful renewal in its theology and praxis starting in the second half of the twentieth century. In the last decades we are experiencing the discovering of the Fathers by different Evangelical traditions and with the Fathers very often comes a renewed appreciation of the liturgy as theologia prima and the irreplaceable role of symbols and rites in Christian life.

By the end of the fourth century the still united Church faces the new challenge of mass conversions with the development of the catechumenate, i.e. a long and profound preparation for Christian Initiation, usually received in the Easter Vigil. Within this framework some extant documents witness to the role played by symbols and rituals in conforming Christian life. Stemming from the Eastern (Jerusalem and Antioch) but also from the Western (Milan) regions they have in common the belief that rituals speak by themselves and even in a stronger way than rational discourse. The process of catechumenate is marked by rites that gradually introduce the candidates into Christian life, culminating in the Easter night through bathing, anointing, eating and drinking. Significant is, however, that the candidates would only receive explanation of the rites after they were 
performed, in the Easter week. At the basis of this approach is the so-called mystagogical method[1], the conviction that rites express by themselves in a powerful manner. The Catechesis of Jerusalem (from Cyril or his successor, John), the Catechetical Homilies of Theodore of Mopsuestia along with the Baptismal Homilies of John Chrysostom in the East, but also both treatises (De mysteriis and De sacramentis) of Ambrose of Milan witness with different nuances to the mystagogical approach, namely the introduction into the mysteries and the Mystery itself by means of ritual actions.

In the present study, I will focus on John Chrysostom's Baptismal Homilies. John, known after the 5th-6th century as the "Golden Mouth", the Chrysostom was born around 349 , being baptized by bishop Meletios in 368. He became a monk and hermit for some years and eventually he was ordained a presbyter in 386. Twelve years later he was appointed as bishop of the Empire's capital. Tried in 403 at the so-called Oak synod, he was sent to exile, recalled, and definitively exiled in 404, where he died in 407.

$\mathrm{He}$ is one of the most prolific authors ever and one of the most-read Fathers of the Church, mainly through his moral emphasis and accessible style. Among his immense oeuvre, we can distinguish 16 treatises (for instance, the very popular one "On Priesthood"), 240 letters, and especially more than 700 sermons. Here we have homilies, commentaries (that comment entire books of the Bible) and speeches. The so-called "Divine Liturgy", the most widespread liturgical form in the Eastern Churches may base to some extent upon an authentic work of John. Finally, not so well known as other writings, we have 12 baptismal catecheses[2] (while the Easter homily, read in the Easter night in Orthodox Churches does not belong to him).

These Baptismal Homilies have been discovered relatively late. Indeed, two "baptismal" catechesis of Chrysostom were published in 1609. Exactly 300 years later, in 1909 A. Papadopoulos-Kerameus published four catechesis that he had found in a Greek manuscript at the library of the Holy Synod of the Russian Church in Moscow, among which there was also the first of the catechesis published in 1609[3]. Half a century later, in 1955, A. Wenger discovered in a codex of the Stavronikita Monastery, in Athos, a series of eight authentic "Catechetical homilies to the Candidates for Baptism and the Newly Baptized" (from which seven were until then unknown), which he edited and published in 1957. [4]

These twelve catechesis have to be dated to the time John was a presbyter in Antioch, more concretely in the decade 387-397. A more precise timely framework can be drawn from the catechesis themselves. Homily 1 was held for Holy Wednesday of 387. 2/1-4 are from the following year (2/1: 30 days before Easter, 2/2: 20 days before, 2/:3 again in Holy Wednesday, and finally 2/4: for Easter, all of them 388). The next series (3/1-7) take a broader framework: 389-397 (3/1-2: Beginning and End of Lent; 3/3: Easter; 3/4-7: Easter Week). The use in Antioch was different from the one in Jerusalem and Milan, where the bishop was in charge of the instruction for the Christian Initiation. Due to the huge number of candidates in Antioch, many priests had this catechetical task and highly probably (if his catechesis are not dated to his time as bishop of Mopsuestia), Theodore and John held at the same time their instructions. A brief reading of both texts brings to light the clear different approach of both of them to their audience. Theodore, as Cyril, comments the creed of their local Church, while John's presentations lack a systematic view and focus upon Christian life and moral, providing neither a system nor a detailed description of Christian initiation and its rites. Unlike Theodore, Cyril, and Ambrose, John refers only to baptism. 
The broad background against which we ought to set John's Catechesis is the context of the above-referred baptismal/mystagogical catechesis in the second half of the fourth century. In passing, it needs to be stated that profound changes take place in the Church of that time. Among other, I want to point out at the emergence and inflation of the notion of "sacred", which can be put in relation with the "discovery" of the "Holy Places" in Palestine. This new view had radical impact on the liturgy and the sacraments [5]. Relevant for us are contemporary liturgical sources as well; many of which have already been mentioned. First of all are the 16 Catechetical Homilies of John's friend, Theodore of Mopsuestia [6]. In them, he comments on the Symbol of Faith or Creed (1-10), the Lord's Prayer (11), and then on the rites of Christian Initiation: Baptism and Anointment (12-14) and Eucharist (15-16). I have already referred to the different methods between both Antiochene priests. Also the reception of them is totally opposed; while John has been acclaimed as a Church Father, the situation is complex regarding Theodore, mainly due to the (posthumous) relation of the Nestorian theology with him.

Cyril of Jerusalem is the author of 18 baptismal catechesis, preceded by a "precatechesis", in which Cyril after establishing the fundaments of Christian faith, comments upon the Creed of the Church of Jerusalem. In addition to these, we have a set of five Mystagogical Catecheses[7]. It has been much debated if these were penned by Cyril or his successor John of Jerusalem. In any case, there are clear liturgical differences between the baptismal and mystagogical catechesis. While the first are to be dated around 349, the latter ought to be in the eighties. These 5 catechesis refer to: 1: Prebaptismal rites 2. Baptism. 3. Anointment 4. Theology of Eucharist. 5. Eucharistic Celebration. [8]

Ambrose of Milan is an emblematic character of that time. He stands still today as an ecumenical saint, a witness of the undivided Church, a Church, which was not divided by the diversity of its forms and approaches. A governor suddenly converted into a bishop, who deeply influenced Western Christianity even being instrumental in the conversion and even Christian Initiation of the most important Western theologian, Augustine. Regarding to our topic, we found two writings, De mysteriis and De sacramentis.[9] Also here, much debate has taken place on the issue of the mutual relationship of both works. In any case, they offer the mystagogical method of the bishop of Milan, within the framework of the developing catechumenate and by commenting the different rites, he introduces us into the core of Ambrose's theology and spirituality.

Further relevant sources are the Apostolic Constitutions, to be situated by the end of the fourth century also in the Antiochene context, and the previous documents of the Apostolic Tradition (beginning of the third century) and the Didache (end of the first century); both of them received in the Apostolic Constitutions. In the writings of the end of the fourth century, chiefly in Cyril, Theodore, and Ambrose, we discover clear patterns in the structure of Christian Initiation. In following, I will present this scheme, in order to focus then in the presentation of that Initiation, drawn from John's catechesis.

In the general structure of the preparation for the Christian Initiation we find three periods: the Precatechumenate, the Catechumenate, and the Enlightenment and Initiation.

In the Precatechumenate the First Step was the acceptance into Order of Catechumens. From then on he or she becomes a catechumen and with this starts the second period: The Catechumenate: Catechumen (the one who is instructed) or hearer (audiens, auditor). According to some sources, like the Apostolic Tradition, this period would take at least three years, although many candidates would extend this time. Here the case of Ambrose could be referred, who coming from a Christian family, was not baptized when he 
was elected bishop of Milan. The catechumens were allowed only to the first part of the liturgy, being required to leave before the Eucharistic part began. This is why that section is still called "liturgy of the Catechumens". Usually the day before the beginning of Lent, those who wanted to be baptized for Easter had to give their names (nomen datio), to register. The following day, within a public ceremony the candidates are brought to the bishop, one by one, and the bishop asks other Christians and the candidates' sponsors about the life of the candidates. Eventually the names of the (successful) candidates are written down by the bishop himself. From then on they received the name of "applicants" (competentes), "chosen" (electi) or "destined for illumination" ( photizomenoi).

With this starts the last period the one of Enlightenment and posterior Initiation. The candidates receive a very intensive preparation, consisting of lectures and rites. They took part in the liturgy and listened to catechesis, which chiefly focused on a series of expositions on the Creed, but also in Ambrose had a moral emphasis with stories of the patriarchs or the precepts of the book of Proverbs. The candidates were bound to secrecy about what they heard in those lectures; the disciplina arcana. Besides the almost daily instruction, centred, not lest relevant are the rites of exorcism. These took part also daily and where highly dramatic. The different reports inform us with some detail. The candidates were standing, with stretched hands and eyes lowered. They were naked and standing barefoot on sack-cloth.

In addition, they received frequent scrutinies by the community and by the bishop and were taught mainly two texts that they had to learn by heart without putting them in writing: the Creed and the Lord's Prayer. They were taught these documents (tradditio) and a week later, they had to publicly pronounce them (redditio). Lent, as for every Christian, was also for them a time of penance and before baptism they need to confess their sins. After which, they received a prebaptismal bath.

The last and most important step was the Christian Initiation itself, consisting of baptism, anointment, and Eucharist. The structure of baptism, which takes place outside the church, in the baptistery, often in very dramatic terms, consists of a rite of Opening (Ephphetha) only in the West, by which the candidates' nostrils (lips) were touched by saliva or oil, as a symbol of the opening to God's grace. Afterwards, the candidates had to renounce to sin, profess their faith, and get naked, be anointed with oil. Before baptism a prayer is said over the baptismal water. After baptism itself, the recently baptized were anointed with Chrism; their feet were washed and they received baptismal garments. Eventually they were brought into the church and would take part for first time in the Eucharistic liturgy. The different rites described are the preparation of the Gifts, the Washing of hands (lavabo), the Kiss of Peace, and the Eucharistic Prayer (anaphora; which has in general the following structure: a. Introductory Dialogue; b. Preface and Sanctus; c. Narration of God's Good Deeds; d. Anamnesis; e. Prayer of Offering; f. Epiclesis over the Offerings; g. Epiclesis over the People; h. commemoration of the Living and Dead. After this comes Communion, preceded by the Recitation of the Lord's Prayer, the breaking of the Bread, the mingling of Body and Blood and preparation for communion. The celebration closes with the post-communion with prayers and rites.

Having presented this general structure of Catechumenate and Initiation by the end of the fourth century, it is time to focus on the same structure, this time by exclusively drawing from John's catechesis. In general, there are not many essential differences from what we have above observed regarding structures and stages. 
Regarding the preparation, John refers to the inscription of the names and when it

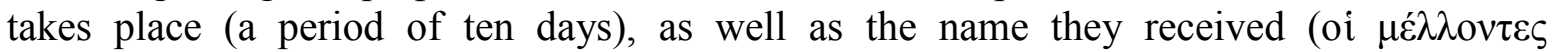
$\varphi \omega \tau i \zeta \varepsilon \sigma \theta \alpha 1$, illuminandi) and the role played by the sponsors ("spiritual Fathers") [10]. According to John, the Pre-Easter catechesis takes 30 days (the inscription of the names, as stated above, started at the beginning of Lent and took ten days). They were held by the bishop and different priests. They were exhortations, rather than a systematic instruction on the fundaments of the faith. After the daily catechesis, the candidates were sent to the exorcists (that in Antioch built an own ordo or $\tau \dot{\alpha} \xi l \varsigma$ ). There, they had to stand naked in the upper part of their bodies, with their hands on the back, as slaves of Satan [11]. "But something else is made known to us by the outward attitude - the bare feet ant the outstretched hands. Just as those who suffer bodily captivity show by the appearance they present their dejection at the disaster that has struck them, so do those men who have been captives of the devil. As they are about to be freed from his tyranny and go beneath the yoke that is easy, first of all they remind themselves by their appearance of their previous situation and try to understand what they are being saved from and what they are hastening to" $[12]$.

Regrettably, we do not know the texts and prayers of those exorcisms. Another element was the First Profession of Faith (from which we have no description by John), After ending the catechesis, the Redditio took place with the bishop. Renunciation to the Devil and Adhesion to Christ: Here we can observe a liturgical evolution, since at John's time these did not take place immediately before baptism, perhaps due to the great number of candidates. The rite consisted in kneeling, with hands stretched to heaven. Let's listen to John's description: "Now consider once again the posture of captivity. The priests who introduce you first of all tell you to kneel down and pray with your hands raised to heaven.... After that the priest approaches each in turn and demands your contracts and confessions and instructs each one to pronounce those fearful and awesome words: I renounce you, Satan, ... your power, your worship and your works. There is great power in these few words. For the angels who are present and the invisible powers rejoice at your conversion and, receiving the words from your lips, carry them to the common master of all things, where they are inscribed in the book of heavens" [13].

The second part is the association with the Lord. Indeed,"After the renunciation of the Evil One and all the works he delights in, the priest instructs you to speak again as follow:

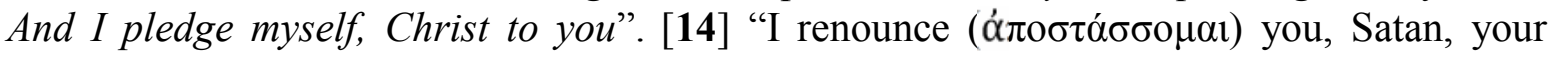

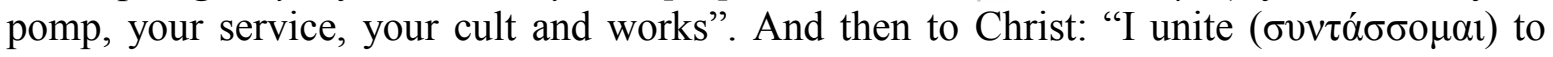
you, Christ". After these rites, came the anointment of the forehead and the Sealing. For the anointment in form of a cross we have the formula: „So and do is anointed in the Name of the Father, the Son, and the Holy Spirit" [15].

It is worthwhile noting that this prebaptismal anointment had for John an exorcistic meaning; he did not understand it as transmission of the Holy Spirit. In addition to this, Chrysostom does not refer to any postbaptismal sealing (unlike Theodore and the Apostolic Constitutions). This rite might have been introduced in the last decade of the $4^{\text {th }}$ century. After all this preliminary actions have taken place, Christian initiation - baptism and Eucharist - may begin. Unlike other authors, John introduces a pause in between. The following rites will take place in the Easter vigil. This consists of the anointment of the whole body, the second profession of faith, baptism and the signs of this, the celebration of the Eucharist and, eventually, the Post-Easter Catechesis. The anointment of the whole body occurs with the same oil utilized before. The anointment is carried out by deacons. It is 
obvious, that women (deaconesses?) would do this with the female candidates. However, unlike the Apostolic Constitutions, John does not explicitly name "deaconesses". That anointment is understood by John as protection against the devil. Immediately before baptism, the second profession of faith, perhaps in a very short form, takes place [16]. For baptism [17], each candidate enters naked into the baptismal font and they are submerged

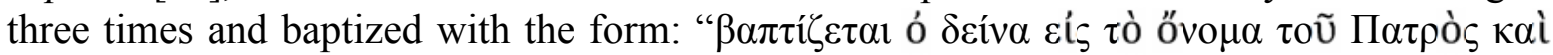

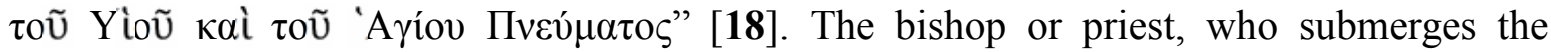
candidate, is regarded as a symbol of Christ.

As the priest pronounced the words, ' $N$. is baptized in the name of the Father and of the Son and of the Holy Spirit', he plunges your head into the water and lifts it up again three times, by this sacred rite preparing you to receive the descent of the Holy Spirit. For the priest is not only the one who touches your head: Christ also touches it with his right hand. This is shown by the actual words of the one who baptizes you. He does not say, ' $I$ baptize N.', but rather, ' $N$. is baptized'. This shows that he is only the minister of the grace and merely lends his hand since he has been ordained for this by the Spirit. It is the Father, Son and Holy Spirit, the indivisible Trinity, who bring the whole rite to completion" [19].

As an effect of baptism, appears the transforming coming of the Spirit [20]. "Then by those words of the priest and by his hand the presence of the Holy Spirit flies down upon you and another man comes up out of the font, one washed from all the stain of his sins, who has put off the old garment of sin and is clothed in the royal robe". [21] In interpreting the baptism, John bases upon the theology of the sixth chapter of the Letter to the Romans. After baptism, the newly baptized receives the sign of a white garment [22], being afterwards embraced and kissed by all [23].

Regrettably, Chrysostom does not provide us with much information about the Eucharist. While he refers to its different names, almost nothing appears regarding the Eucharistic liturgy and its rites. This silence could be explained by the Arcanum, although the other authors provide us with much more information in this sense. In any case, John understands the Eucharist mainly as food for the baptized. Finally, there is some mention about Post-Easter Catechesis, which take place in the seven days following baptism and Easter. In any case, they are not mystagogical catechesis in the full sense of a theological explanation of the liturgical rites that occurred during the Christian initiation, but rather spiritual instructions. Also here we observe John's moral focus and emphasis.

\section{Conclusions}

First of all, it is important to replace John's catechesis within the Antiochene framework, noting in the meantime that the same context led to totally different approaches than his friend Theodore. It is anyway a context, where we have developed structures for the catechumenate and a large number of candidates. This constitutes a real challenge for the Church at that time. John is also witness to a particular stage in the liturgical evolution regarding the rites of baptism and Eucharist. Especially relevant is the absence here of a postbaptismal anointment. In other authors, mainly in Cyril's mystagogical catechesis, we observe a very developed Pneumatology in this sacrament but also within the Eucharist, chiefly in the anaphora. Although John's catechesis cannot be considered mystagogical, at least to the degree we find it in Cyril and Theodore, the mystagogical method, so relevant today in liturgical studies, is not absent. In this sense, he could say: "It is not without good reason and careful thought that I have explained all these things to you in advance, my loving people. Even before you actually enjoy them, I wanted you to feel great pleasure as you fly on the wings of hope..." [24]. 


\section{REFERENCES}

[1] Cf. Hugh M. Riley, Christian initiation: a comparative study of the interpretation of the baptismal liturgy in mystagogical writings of Cyril of Jerusalem, John Chrysostom, Theodore of Mopsuestia and Ambrose of Milan, Washington DC: Catholic University of America Press, 1974. Also E. Mazza, La mistagogia. Una teologia della liturgia in epoca patristica. Rome 1988. English translation: Mystagogy. A Theology of Liturgy in the Patristic Age. New York 1989. Also Wenrich Slenczka, Heilsgeschichte und Liturgie: Studien zum Verhältnis von Heilsgeschichte und Heilsteilhabe anhand liturgischer und katechetischer Quellen des dritten und vierten Jahrhunderts, Berlin 2000. Edward Yarnold, The awe-inspiring rites of initiation: the origins of the RCIA. Edinburgh 1994.

[2] English translation in Paul W. Harkins (ed.) John Chrysostom. Baptismal instructions, New York 1963. Critical text and German Translation in Reiner Kaczynski (ed.) Johannes Chrysostomus. Catéchèses baptismales: griechisch - deutsch = Taufkatechesen. Freiburg - Wien 1992. (2 vol).

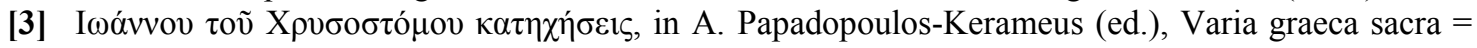
Studia byzantina lucis ope iterata 6, Leipzig 1975, 154-183 (St. Petersbourg 1909).

[4] A. Wenger (ed.), Saint Jean Chrysostome, Huit catéchèses baptismales inédites. Paris3 1985.

[5] Cf P. Argárate, 'L'influence de Constantin sur l'émergence de la notion de 'lieux saints' au IVème siècle", in: Actes du VIème colloque de Patristique de La Rochelle. "Les Pères de l'Eglise et les enjeux du pouvoir", Caritas Patrum, Royan, 2014, pp 223-237. Also P. Argárate, "The End of Christian U-Topy? On the Emergence of the Notion of "Holy Places" and "Holy Land" in the Fourth Century", in: Viorel Sava, Pablo Argárate and Nicolae Pintilie (eds.), Studia Theologica Doctoralia V, Iaşi 2013, pp. 9-14. Also P. Argárate, "Liturgical Evolution in Jerusalem by the End of the Fourth Century”, in: Pr. Ion Vicovan, Emilian-Iustinian Roman (ed.): Laicii şi misiunea creştină, Realitate istorică, vocaţie personală, necesitate eclesială. Iaşi 2014, pp. 100-109.

[6] R. Tonneau-R. Devresse (ed.), Les homélies catéchétiques de Théodore de Mopsueste. Rome 1961. Cf. P. Argárate, “L’Eglise, les sacrements et l'Esprit Saint dans les homélies catéchétiques de Théodore de Mopsueste", in André Lossky - Manlio Sodi (eds.), La Liturgie témoin de l'Église. Conférences Saint-Serge: LVIIe Semaine d'Études Liturgiques (Monumenta Studia Instrumenta Liturgica 66). Città del Vaticano 2012, pp 105-116.

[7] Auguste Piédagnel (ed.), Cyrille de Jérusalem, Catéchèses mystagogiques. Paris 1966.

[8] Cf. Juliette Day, The Baptismal Liturgy of Jerusalem: Fourth- and Fifth-Century Evidence from Palestine, Syria and Egypt. Aldershot 2007. Also P. Argárate, "Les rites eucharistiques dans les catéchèses de Cyrille de Jérusalem”. In A. Lossky -M. Sodi (eds.). Rites de Communion. Conférence Saint-Serge. LVe Semaine d'études liturgiques. Paris, 23-26 June 2008. Città del Vaticano 2010, pp 115-129.

[9] Otto Faller [ed.], Sancti Ambrosii Opera. 7. Corpvs scriptorvm ecclesiasticorvm Latinorvm; 73. Vienna 1955. Ambroise de Milan, De sacramentis. De mysteris, Bernard Botte (ed.), Paris 1961.

[10] Cf. Baptismal Homilies, 3/2, 15-16.

[11] Cf. Baptismal Homilies, $2 / 2$.

[12] Baptismal Homilies, 3/2.14.

[13] Baptismal Homilies, 3/2, 18-20.

[14] Baptismal Homilies, 3/2. 21.

[15] Baptismal Homilies, 2/3.

[16] Baptismal Homilies, 2/4.

[17] Baptismal Homilies, 2/3. Cf. T.M. Finn, The Liturgy of baptism in the Baptismal Instructions of St. John Chrysostom. Washington D.C. 1967. Also André Benoît, - Charles Munier (ed.), Die Taufe in der Alten Kirche: (1.-3. Jahrhundert), Bern 1994. Everett Ferguson, Baptism in the early church: history, theology, and liturgy in the first five centuries, Grand Rapids 2009.

[18] Baptismal Homilies, 2/3.

[19] Baptismal Homilies, 3/2. 26.

[20] Cf. Baptismal Homilies, 3/2.10.

[21] Baptismal Homilies, 3/2. 25.

[22] Cf. Baptismal Homilies, 3/3; 3/6.

[23] Cf. Baptismal Homilies, 2/3.

[24] Baptismal Homilies, 3/2. 28. 